\title{
A novel organosilicon-based ionic plastic crystal as solid-state electrolyte for lithium-ion batteries*
}

\author{
Xin-yue ZHAO ${ }^{1}$, Jing-lun WANG ${ }^{1}$, Hao LUO ${ }^{1}$, Hu-rong YAO ${ }^{2}$, Chu-ying OUYANG ${ }^{2}$, Ling-zhi ZHANG ${ }^{\dagger 1}$ \\ $\left({ }^{1}\right.$ Key Laboratory of Renewable Energy, Guangzhou Institute of Energy Conversion, \\ Chinese Academy of Sciences, Guangzhou 510640, China) \\ ( ${ }^{2}$ College of Physics and Communication Electronics, Jiangxi Normal University, Nanchang 330022, China) \\ †E-mail: lzzhang@ms.giec.ac.cn \\ Received May 5, 2015; Revision accepted Aug. 5, 2015; Crosschecked Jan. 25, 2016
}

\begin{abstract}
A novel organosilicon-based ionic plastic crystal, $N, N, N$,-diethylmethyl- $N$-[(trimethylsilyl)methyl]ammonium bistrifluoromethane sulfonimide ([DTMA][TFSI]) was designed and synthesized as solid-state electrolyte for lithium-ion batteries. The chemical structure and the physical and electrochemical properties were characterized in detail. The ionic conductivity of [DTMA][TFSI] was improved significantly by doping with lithium oxalyldifluoroborate (LiODFB) and propylene carbonate (PC). An optimized plastic crystal composite ([DTMA][TFSI]:LiODFB:PC=8:1:1 in molar ratio) as a solid-state electrolyte exhibited a decent cycling stability in $\mathrm{LiFePO}_{4} / \mathrm{Li}$ half-cell, with a specific discharge capacity of $144 \mathrm{~mA} \cdot \mathrm{h} / \mathrm{g}$ and capacity retention of $94 \%$ after 50 cycles at $\mathrm{C} / 20$.
\end{abstract}

Key words: Organosilicon, Ionic plastic crystal, Solid-state electrolyte, Lithium-ion battery http://dx.doi.org/10.1631/jzus.A1500099

CLC number: 0646

\section{Introduction}

Lithium-ion batteries have been widely used as power sources in portable electronic appliances because of their high energy density and long cycling life. However, commercial carbonate-based electrolytes, which are volatile and flammable, carry inherent drawbacks of leakage and safety problems for lithium-ion batteries (Zhang et al., 2007; Kim et al., 2008). Recently, solid-state electrolytes have received considerable interest due to their applications

\footnotetext{
¿ Corresponding author

* Project supported by the Special Support Program of Guangdong Province for High-level Talents (No. 2014TX01N014), the Guangdong Provincial Project for Science \& Technology (Nos. 2013B091300017 and 2014A050503050), the Guangzhou Municipal Project for Science \& Technology (No. 201423/2014Y2-00219), and the Dongguan Municipal Collaboration Project for Industry \& Science (No. 2013509104210), China

(1D) ORCID: Xin-yue ZHAO, http://orcid.org/0000-0001-9097-771X

(c) Zhejiang University and Springer-Verlag Berlin Heidelberg 2016
}

covering a range of electrochemical devices, owing to their advantages of high safety, reduced leakage, excellent stability, as well as improved energy density and shape variability (Tarascon and Armand, 2001; Hammami et al., 2003; Rana et al., 2012). Among the solid-state electrolytes, organic ionic plastic crystals (OIPCs) represent a unique and complex family, members of which utilize a relatively large and symmetric organic cation in combination with an inorganic or organic anion. Used as a potential electrolyte for electrochemical devices, OIPCs possess many advantages such as excellent thermal stability, wide electrochemical window, high ionic conductivity, and nonflammability (MacFarlane and Forsyth, 2001; Wang et al., 2013; Taniki et al., 2014).

Recently, research on OIPCs mainly has focused on quaternary ammonium cations such as imidazolium, pyrrolidinium (Alarco et al., 2004; Howlett et al., 2011; Horike et al., 2012), and quaternary phosphonium (Armel et al., 2011). There are many studies on the structure and properties of new cations 
and anions. The ionic liquids based on $N, N$-dialkyl3-azabicyclo[3.2.2]nonanium cations exhibit plastic crystal properties and excellent lithium depositionstripping behavior (Ruther et al., 2007). Moriya et al. (2014) reported that new OIPCs, which were produced from cyclic perfluorosulfonylamide anion and cyano-substituted quaternary ammonium cations, had a wide plastic crystal temperature range, from about $-30{ }^{\circ} \mathrm{C}$ to $250{ }^{\circ} \mathrm{C}$. Armel et al. (2011) synthesized a range of OIPCs using phosphonium cations for the first time. To use OIPCs as potential solidstate electrolyte materials in lithium-ion batteries, the ionic conductivity and electrode compatibility of these materials have to be improved. Usually, these two properties could be circumvented by doping with a second component (such as lithium salts and nanoparticles) and using preconditioning process (Pringle, 2013; Unemoto et al., 2014). Shekibi et al. (2012) have reported that $N$-ethyl- $N$-methylpyrrolidinium tetrafluoroborate $\left(\left[\mathrm{C}_{2} \mathrm{mpyr}\right]\left[\mathrm{BF}_{4}\right]\right)$ was used as an ionic plastic crystal solid-state electrolyte for the lithium battery. Their results revealed that $\left[\mathrm{C}_{2} \mathrm{mpyr}\right]\left[\mathrm{BF}_{4}\right]$ doping with $10 \% \mathrm{LiBF}_{4}$ exhibited viable ionic conductivity at the level of $10^{-3} \mathrm{~S} / \mathrm{cm}$ at $100{ }^{\circ} \mathrm{C}$, and the discharge capacity in $\mathrm{LiFePO}_{4} / \mathrm{Li}$ cell was about $100 \mathrm{~mA} \cdot \mathrm{h} / \mathrm{g}$ at $80{ }^{\circ} \mathrm{C}$ with current density of C/10. Sunarso et al. (2012) studied the preconditioning behavior by low current $\left(0.01 \mathrm{~mA} / \mathrm{cm}^{2}\right.$ at $\left.50{ }^{\circ} \mathrm{C}\right)$ galvanostatic cycling of symmetrical lithium cells to improve the interfacial contact between the OIPCs and the electrodes. The $\mathrm{LiFePO}_{4} / 10 \% \quad \mathrm{LiNTf}_{2}$ in $\left[\mathrm{C}_{2} \mathrm{mpyr}\right]\left[\mathrm{NTf}_{2}\right] / \mathrm{Li}$ cell showed a capacity of $129 \mathrm{~mA} \cdot \mathrm{h} / \mathrm{g}$ and retained $110 \mathrm{~mA} \cdot \mathrm{h} / \mathrm{g}$ after 50 cycles at $\mathrm{C} / 5$.

Organosilicon-based materials have attracted great attention as electrolytes for electrochemical energy storage devices due to their excellent thermal stability, viable ionic conductivity at low temperatures, low flammability, high electrochemical stability, and environmentally benign characters (Shirota and Castner, 2005; Zhang et al., 2008; Rossi and West, 2009; Weng et al., 2011). We have been dedicated to the design and synthesis of organosiliconbased electrolytes, including liquid electrolytes and ionic liquids, for applications in electrochemical energy storage devices such as lithium-ion batteries and supercapacitors (Zhong et al., 2012; Qin et al., 2013; Yan and Zhang, 2013; Yong et al., 2014).

In this work, we report the synthesis of a novel organosilicon-based ionic plastic crystal, $N, N, N,-$ diethylmethyl- $N-[($ trimethylsilyl)methyl] ammonium bistrifluoromethanesul-fonimide ([DTMA][TFSI]). The doping content of LiODFB and PC in [DTMA][TFSI] was optimized. The electrochemical performances of the optimized composition as solid electrolyte were investigated in $\mathrm{LiFePO}_{4} / \mathrm{Li}$ halfcells by galvanostatic charge/discharge and electrochemical impedance spectroscopy (EIS) analysis.

\section{Experimental}

\subsection{Materials}

Methyl iodide $\left(\mathrm{CH}_{3} \mathrm{I}, 99.5 \%\right)$ and silver nitrate $\left(\mathrm{AgNO}_{3}, 99 \%\right)$ were purchased from Aladdin Co. (China). Lithium bis(trifluoromethanesulfonyl)imide (LiTFSI, lithium battery grade) was obtained from Sinoworo (China). LiODFB was purchased from Hongyang Chemical Ltd. (China). Propylene carbonate (PC) was commercially available from Zhangjiagang Guotai-Huarong Co. (China). $\mathrm{LiFePO}_{4}$ was provided by Advanced Electronics Energy Ltd. (China).

\subsection{Procedures for the synthesis of [DTMA][TFSI]}

All reagents were used without further purification; solvents were dried using standard procedures. The organosilicon-based OIPC material used in this work was easily synthesized through a two-step route as outlined in Scheme 1. Typical procedures were as follows: $N$-[(trimethylsilyl)methyl] $-N, N$ diethylamine (0.10 mol, Hasegawa et al. (1988)) was dissolved in $200 \mathrm{ml}$ tetrahydrofuran (THF) and cooled to $0{ }^{\circ} \mathrm{C}$ in an ice bath; then, $\mathrm{CH}_{3} \mathrm{I}(0.11 \mathrm{~mol})$ was added dropwise. After stirring the mixture for $14 \mathrm{~h}$ at $60^{\circ} \mathrm{C}, N, N, N$,-diethylmethyl- $N$-[(trimethylsilyl)methyl]ammonium iodide was obtained as a yellow powder through evaporation of the solvent. The iodide salt was purified by recrystallization with $\mathrm{CH}_{2} \mathrm{Cl}_{2} / \mathrm{Et}_{2} \mathrm{O}$ two times. In the second step, the iodide salt $(0.090 \mathrm{~mol})$ and LiTFSI $(0.095 \mathrm{~mol})$ were dissolved in $80 \mathrm{ml} \mathrm{CH}_{2} \mathrm{Cl}_{2}$ and $50 \mathrm{ml}$ water. After the mixture was stirred for $1 \mathrm{~d}$ at room temperature, the $\mathrm{CH}_{2} \mathrm{Cl}_{2}$ phase was collected and washed with deionized water many times until no white precipitation was observed upon adding $1 \% \mathrm{AgNO}_{3}$ into the water phase. Then the $\mathrm{CH}_{2} \mathrm{Cl}_{2}$ was evaporated and 
the target product was recrystallized two times with $\mathrm{CH}_{2} \mathrm{Cl}_{2} / \mathrm{Et}_{2} \mathrm{O}$, giving white needle-like crystals. The [DTMA][TFSI] was dried under vacuum at $100^{\circ} \mathrm{C}$, with overall yield of $88 \%$.

$$
\begin{gathered}
\left(\mathrm{CH}_{3}\right)_{3} \mathrm{SiCH}_{2} \mathrm{~N}\left(\mathrm{CH}_{2} \mathrm{CH}_{3}\right)_{2} \stackrel{\mathrm{CH}_{3} \mathrm{I}}{\longrightarrow}\left(\mathrm{CH}_{3}\right)_{3} \mathrm{SiCH}_{2} \stackrel{+}{\mathrm{N}}\left(\mathrm{CH}_{2} \mathrm{CH}_{3}\right)_{2} \mathrm{CH}_{3} \mathrm{I}^{-} \\
\stackrel{\text { LiTFSI }}{- \text { LiI }}\left(\mathrm{CH}_{3}\right)_{3} \mathrm{SiCH}_{2} \stackrel{+}{\mathrm{N}}\left(\mathrm{CH}_{2} \mathrm{CH}_{3}\right)_{2} \mathrm{CH}_{3} \text { TFSI }
\end{gathered}
$$

\section{Scheme 1 Route for synthesis of [DTMA][TFSI]}

The chemical structure of [DTMA][TFSI] was confirmed by nuclear magnetic resonance (NMR) and Fourier transform infrared spectroscopy (FTIR):

${ }^{1} \mathrm{H}$ NMR of [DTMA][I] $\left(600 \mathrm{MHz}, \mathrm{CDCl}_{3}, \delta\right)$ : 3.54-3.58 (m, $\left.4 \mathrm{H}, \mathrm{CCH}_{2} \mathrm{~N}\right), 3.26\left(\mathrm{~s}, 3 \mathrm{H}, \mathrm{NCH}_{3}\right)$, 3.22 (s, $\left.2 \mathrm{H}, \mathrm{SiCH}_{2} \mathrm{~N}\right), 1.39-1.41$ (t, $6 \mathrm{H}, \mathrm{CH}_{3} \mathrm{CN}-$ ), $0.30\left(\mathrm{~s}, 9 \mathrm{H}, \mathrm{SiCH}_{3}\right) .{ }^{1} \mathrm{H}$ NMR of [DTMA][TFSI] $\left(600 \mathrm{MHz}, \mathrm{CDCl}_{3}, \delta\right): 3.32-3.36\left(\mathrm{~m}, 4 \mathrm{H}, \mathrm{CCH}_{2} \mathrm{~N}\right)$, $3.01\left(\mathrm{~s}, 3 \mathrm{H}, \mathrm{NCH}_{3}\right), 2.91\left(\mathrm{~s}, 2 \mathrm{H}, \mathrm{SiCH}_{2} \mathrm{~N}\right), 1.36-1.37$ (t, $\left.6 \mathrm{H}, \mathrm{CH}_{3} \mathrm{CN}\right), 0.28\left(\mathrm{~s}, 9 \mathrm{H}, \mathrm{SiCH}_{3}\right) \cdot{ }^{13} \mathrm{C}$ NMR of [DTMA][TFSI] $\left(150 \mathrm{MHz}, \mathrm{CDCl}_{3}, \delta\right): 0.42,9.67$, $52.14, \quad 56.19, \quad 60.80, \quad 119.85 \quad\left(\mathrm{q}, \quad J_{\mathrm{CF}}=214.8\right)$. ${ }^{29} \mathrm{Si}$ NMR of [DTMA][TFSI] $\left(120 \mathrm{MHz}, \mathrm{CDCl}_{3}, \delta\right)$ : 21.78.

FTIR: $1056 \mathrm{~cm}^{-1}(\mathrm{~S}-\mathrm{N}-\mathrm{S}), 1194 \mathrm{~cm}^{-1}\left(\mathrm{C}-\mathrm{F}_{3}\right)$, $857 / 787 \mathrm{~cm}^{-1}\left(\mathrm{Si}-\mathrm{CH}_{3}\right)$.

\subsection{Preparation of the composite plastic crystal materials and measurements}

LiODFB salt was dried under vacuum for $24 \mathrm{~h}$ at $120^{\circ} \mathrm{C}$ before the organosilicon-based OIPC electrolyte preparation. The mixed electrolyte samples based on [DTMA][TFSI], LiODFB, and PC were prepared in the proportions shown in Table 1, and the mixture was stirred at $80^{\circ} \mathrm{C}$ for $2 \mathrm{~h}$ under argon atmosphere until a clear transparent viscous solution was obtained. These composite samples were allowed to cool to solid state under vacuum at $25{ }^{\circ} \mathrm{C}$ and then transferred to a glove box for the next tests.

Table 1 Formulation of the composite samples

\begin{tabular}{cccc}
\hline Sample & $\begin{array}{c}x \text { (LiODFB) } \\
(\%)\end{array}$ & $\begin{array}{c}x([\mathrm{DTMA}][\mathrm{TFSI}]) \\
(\%)\end{array}$ & $\begin{array}{c}x(\mathrm{PC}) \\
(\%)\end{array}$ \\
\hline IPC1 & 0 & 100 & 0 \\
IPC2 & 10 & 90 & 0 \\
IPC3 & 20 & 80 & 0 \\
IPC4 & 30 & 70 & 0 \\
IPC5 & 10 & 80 & 10 \\
\hline
\end{tabular}

Differential scanning calorimetry (DSC) was performed with a TA-Q100 instrument. All samples were loaded into hermetically sealed aluminum pans and scanned from $-100{ }^{\circ} \mathrm{C}$ to $100^{\circ} \mathrm{C}$ at a scanning rate of $10{ }^{\circ} \mathrm{C} / \mathrm{min}$.

Conductivity measurements were performed using impedance spectroscopy technique. The sample was sandwiched between two stainless steel electrodes with $1.4 \mathrm{~cm}$ diameter and was assembled in an Ar-filled glove box. The impedance spectra were collected in the frequency range of $10 \mathrm{mHz}$ to $2 \mathrm{MHz}$, with signal amplitude of $10 \mathrm{mV}$. The resistance value at which the low-frequency end of the semicircle crosses the $x$-axis of the complex impedance plot was obtained. The temperature was varied between $-20{ }^{\circ} \mathrm{C}$ and $80{ }^{\circ} \mathrm{C}$, allowing $30 \mathrm{~min}$ for thermal equilibration at each temperature. EIS results were obtained with Zennium/IM6 electrochemical workstation (Zahner, Germany).

\subsection{Cell tests}

The coin cells (CR2025) were assembled to test the electrochemical performance using $\mathrm{LiFePO}_{4}$ cathode and lithium foil anode with the IPC5 composite sample as electrolyte. The $\mathrm{LiFePO}_{4}$ electrode was prepared by coating a mixture of $\mathrm{LiFePO}_{4}$, carbon black, and poly(vinylidene fluoride) (PVDF), with a weight ratio of $80: 10: 10$, on aluminum foil using $N$-methyl-2-pyrrolidone (NMP) as a solvent. The active material loading was about $5 \mathrm{mg} / \mathrm{cm}^{2}$. Both separators and cathodes were dried under vacuum at $80^{\circ} \mathrm{C}$ overnight. The cell assembly process was carried out in an argon-filled glove box with oxygen and moisture levels $<1 \times 10^{-6}$. In order to make the electrodes, a separator (Celgard 2400, $\phi=$ $1.6 \mathrm{~cm}, 25 \mu \mathrm{m}$ thickness) and plastic crystal electrolyte (about $110 \mathrm{mg}$ per separator) were well impregnated, and the plastic crystal electrolyte was heated until melting for fabrication. The cells were placed inside high and low gimbals and galvanostatic charging-discharging cycled using a multichannel battery test system (NEWARE BTS-610). The charge and discharge cutoff voltage was from $2.5 \mathrm{~V}$ to $4 \mathrm{~V}$. The EIS results were obtained with Zennium/ IM6 electrochemical workstation (Zahner, Germany) at the end of charging $\left(\mathrm{LiFePO}_{4} / \mathrm{Li}\right)$ with $10 \mathrm{mV}$ perturbation amplitude applied in the frequency range of $10 \mathrm{mHz}-1 \mathrm{MHz}$. 


\section{Results and discussion}

\subsection{DSC and ionic conductivity}

LiODFB, as a lithium salt, is featured by its higher solubility, higher thermal stability, capability of passivating current collector, and forming a stable solid-electrolyte interface (SEI) on the surface of the electrode (Zhang, 2006). The DSC curves of [DTMA][TFSI] with different contents of LiODFB are shown in Fig. 1. The pure [DTMA][TFSI] sample (IPC1) showed plastic crystalline behavior over a wide temperature range, from approximately $-26{ }^{\circ} \mathrm{C}$ to $54{ }^{\circ} \mathrm{C}$, which is an advantage for its application in electrochemical devices at room temperature. The melting point of [DTMA][TFSI] decreased with increase in the doping contents of LiODFB from $54{ }^{\circ} \mathrm{C}$ to $43{ }^{\circ} \mathrm{C}$. The melting peaks became broader after doping with LiODFB, probably due to the formation of crystal defect and the fluctuation of the local crystallite packing and volume change during OIPCliquid transition (Moriya et al., 2014). Nevertheless, these composites remain in the plastic crystal states with clear solid-solid phase transitions and appear as an icy solid, even when LiODFB doping level increased up to $30 \%$. It is known that adding an appropriate proportion of plasticizer can enhance ion mobility, hence increasing the ion conductivity of the electrolyte (Osman et al., 2001; Glasse et al., 2002). Therefore, IPC5 doped with 10\% PC (commonly used plasticizer in gel polymer electrolytes) was prepared to further improve the ion conductivity. The plastic crystal temperature range of the sample IPC5 is from $-26{ }^{\circ} \mathrm{C}$ to $43{ }^{\circ} \mathrm{C}$. As can be seen from the DSC curve (Fig. 1), IPC5 can also remain in the solid state at room temperature.

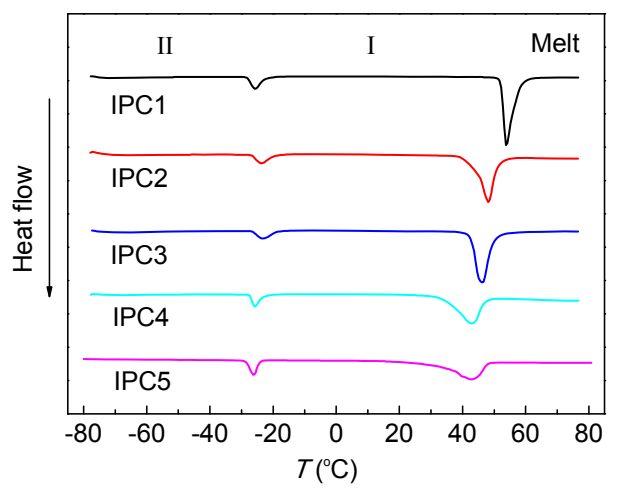

Fig. 1 DSC analysis of pure and [DTMA][TFSI] samples doped with LiODFB and PC
The phase transition temperature and the entropies of fusion $(\Delta S)$ of [DTMA][TFSI] doping with different contents of LiODFB are summarized in Table 2. According to Timmermans (1961)'s criterion, the entropy of fusion for plastic crystal is considered to be $<20 \mathrm{~J} /(\mathrm{mol} \cdot \mathrm{K})$. However, the entropy of melting can be higher for OIPCs because one of its ion species may exhibit rotational motions (MacFarlane et al., 2001). The entropy of fusion of [DTMA][TFSI] turned out to be $63 \mathrm{~J} /(\mathrm{mol} \cdot \mathrm{K})$, doping with LiODFB resulted in decreasing the entropy of fusion. Similarly, $\left[\mathrm{P}_{144}\right]\left[\mathrm{BF}_{4}\right]$ and $\left[\mathrm{P}_{1444}\right][\mathrm{SCN}]$ salts exhibit quite low conductivities, consistent with their high entropies of fusion (44-45)\% $\%$ $5 \% \mathrm{~J} /(\mathrm{mol} \cdot \mathrm{K})$, demonstrating a relatively ordered phase (Armel et al., 2011). The decreased entropy of LiODFB/[DTMA][TFSI] suggests that LiODFB might affect the crystallinity of the plastic crystal, probably owing to the formation of solid solutions as observed in LiTFSI-pyrrolidinium family (Forsyth et al., 2000). IPC5 exhibits a similar phase transition entropy as IPC3, having the same doping level of $20 \%$. However, the melting entropy of IPC5 was slightly lower than that of IPC3, possibly because the PC liquid region could be housed within the extensive dislocation networks known to exist in the plastic crystal phase (Abu-Lebdeh et al., 2004).

Table 2 Phase transition temperature and the entropies of the samples

\begin{tabular}{cccccc}
\hline \multirow{2}{*}{ Sample } & \multicolumn{4}{c}{ Phase transition } \\
\cline { 2 - 3 } & \multicolumn{3}{c}{$\mathrm{II}-\mathrm{I}$} & & \multicolumn{2}{c}{$\mathrm{I}-\mathrm{Melt}$} \\
\cline { 2 - 3 } \cline { 5 - 6 } & $T\left({ }^{\circ} \mathrm{C}\right)$ & $\Delta S(\mathrm{~J} /(\mathrm{mol} \cdot \mathrm{K}))$ & & $T\left({ }^{\circ} \mathrm{C}\right)$ & $\Delta S(\mathrm{~J} /(\mathrm{mol} \cdot \mathrm{K}))$ \\
\hline IPC1 & -26 & 15 & & 54 & 63 \\
IPC2 & -24 & 13 & & 48 & 60 \\
IPC3 & -23 & 11 & & 46 & 58 \\
IPC4 & -26 & 9 & & 43 & 43 \\
IPC5 & -26 & 12 & & 43 & 53
\end{tabular}

Data of $T$ and $\Delta S$ have a margin of error of \pm 1 and $\pm 5 \%$, respectively

The temperature dependence of the conductivities of [DTMA][TFSI] and the ternary composite [DTMA][TFSI]/LiODFB/PC is shown in Fig. 2. The conductivity of IPC1 was $3 \times 10^{-8} \mathrm{~S} / \mathrm{cm}\left(25{ }^{\circ} \mathrm{C}\right)$. However, after doping with $10 \%$ LiODFB, IPC2 showed a conductivity of $4 \times 10^{-8} \mathrm{~S} / \mathrm{cm}$, not much improved compared with pure IPC1. But the conductivity of the sample IPC5 with 10\% LiODFB and 
$10 \% \mathrm{PC}$ in [DTMA][TFSI] was obviously improved. As expected, the sample IPC5 showed a significantly increased conductivity of $1 \times 10^{-4} \mathrm{~S} / \mathrm{cm}$. The conductivities of both IPC1 and IPC5 were increased with the increase of the temperature, and the conductivities of the samples reached about the same level at $60{ }^{\circ} \mathrm{C}$, where the two samples were in liquid states. The composite [DTMA][TFSI]/LiODFB/PC sample exhibited moderate conductivity and could be maintained in the solid state at room temperature (Fig. 3), so it was chosen as solid-state electrolyte for the following electrochemical tests.

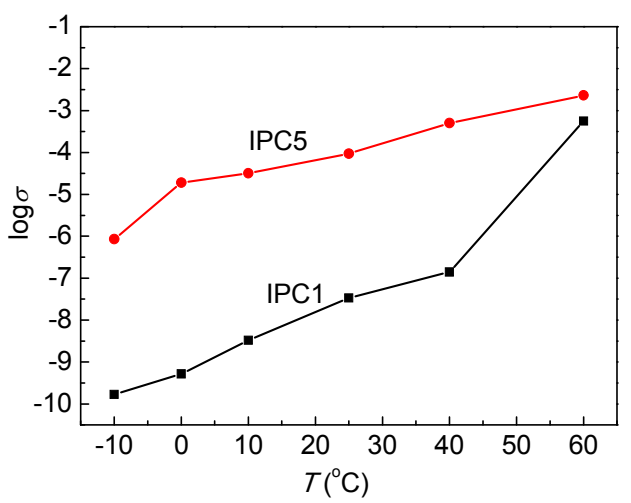

Fig. 2 Temperature dependence of conductivity of IPC1 and IPC5
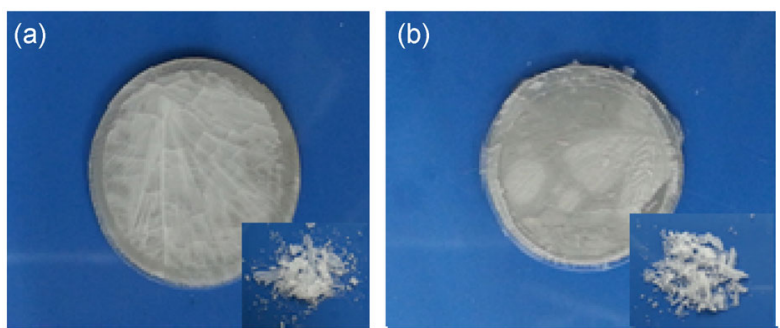

Fig. 3 Photographs of IPC1 (a) and IPC5 (b) at room temperature

\subsection{Cell tests}

The electrochemical performance of the sample IPC5 as solid-state electrolyte for $\mathrm{LiFePO}_{4} / \mathrm{Li}$ halfcells was investigated in detail. Fig. 4 presents the initial and the third galvanostatic charge-discharge curves for the $\mathrm{LiFePO}_{4} / \mathrm{IPC} 5 / \mathrm{Li}$ cell cycled with the current density of $\mathrm{C} / 20(8 \mathrm{~mA} / \mathrm{g})$ and the cutoff voltage range of $2.5-4.0 \mathrm{~V}$ at room temperature. The cell showed an initial charge-discharge capacity of $156 / 137 \mathrm{~mA} \cdot \mathrm{h} / \mathrm{g}$ and a Coulombic efficiency of $88 \%$. At the third cycle, the cell delivered a discharge capacity of $144 \mathrm{~mA} \cdot \mathrm{h} / \mathrm{g}$ with a higher Coulombic efficiency of $99 \%$. Moreover, the polarization was also decreased in the third cycle, which could be observed distinctly in Fig. 4. EIS was used to characterize the impedance properties of the $\mathrm{LiFePO}_{4} /$ IPC5/Li cell (Fig. 5). The Nyquist plots of the impedance spectra consisted of one large depressed semicircle in the high-frequency region and a straight line in the low-frequency region, which correspond to the charge transfer process and Warburg diffusion impedance, respectively. Comparing the impedance spectra of the cell after the first and the third cycles, it was observed that the charge transfer impedance decreased from $800 \Omega$ to $360 \Omega$ after three cycles. The decrease of impedance with increasing cycles might be attributed to the formation of a passivation layer and good contact compatibility between lithium and the solid-state electrolyte interface (Sunarso et al., 2012), which could be the reason for the capacity increase during the first three cycles.

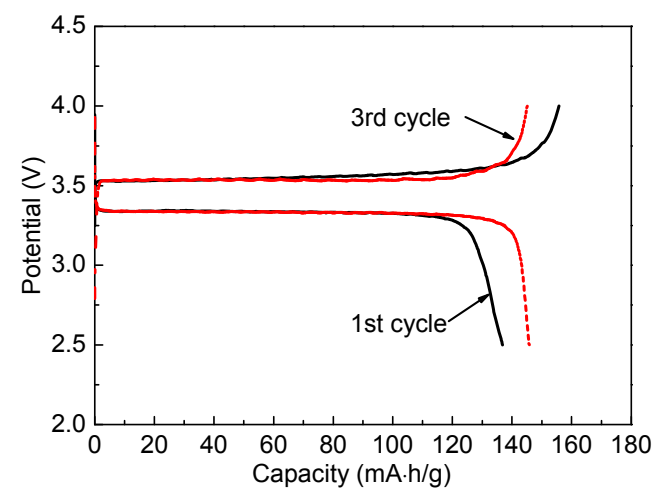

Fig. 4 Galvanostatic cycle curves of $\mathrm{LiFePO}_{4} / \mathrm{IPC5} / \mathrm{Li}$ cell for the first cycle and the third cycle

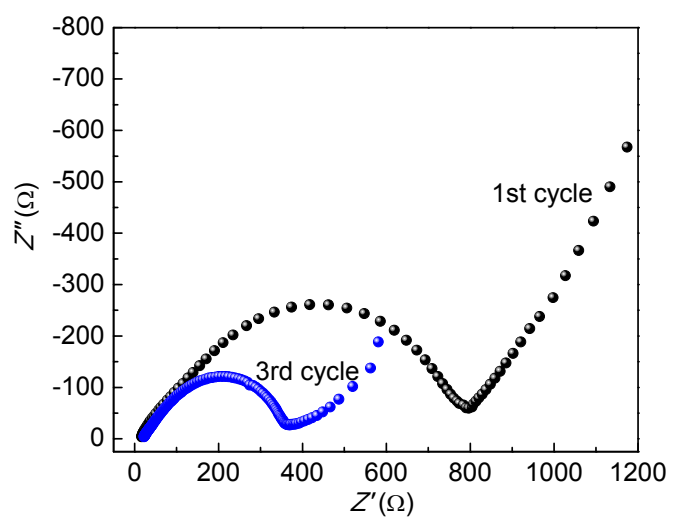

Fig. 5 Impedance spectra of the cell after the first and the third cycles

The cycling performance of the $\mathrm{LiFePO}_{4} / \mathrm{IPC} 5 /$ $\mathrm{Li}$ cell at the current rate of $\mathrm{C} / 20$ is displayed in 
Fig. 6. The cell exhibited excellent cycle performance with specific discharge capacity of $144 \mathrm{~mA} \cdot \mathrm{h} / \mathrm{g}$ and Coulombic efficiency of $99 \%$ after 50 cycles, and the overall capacity retention turned out to be $94 \%$. The rate performance of $\mathrm{LiFePO}_{4} /$ IPC5/Li cell at various current densities was measured at room temperature (Fig. 7). At $\mathrm{C} / 10, \mathrm{C} / 12$, $\mathrm{C} / 20$, and $\mathrm{C} / 24$, the cell displayed a specific capacity of $100 \mathrm{~mA} \cdot \mathrm{h} / \mathrm{g}, 126 \mathrm{~mA} \cdot \mathrm{h} / \mathrm{g}, 143 \mathrm{~mA} \cdot \mathrm{h} / \mathrm{g}$, and $158 \mathrm{~mA} \cdot \mathrm{h} / \mathrm{g}$, respectively. However, the specific capacity of the cell faded rapidly when the current density was above $\mathrm{C} / 8$ rate, which may be related to the limited ionic conductivity of the solid-state electrolyte and the charge transfer resistance of the SEI film.

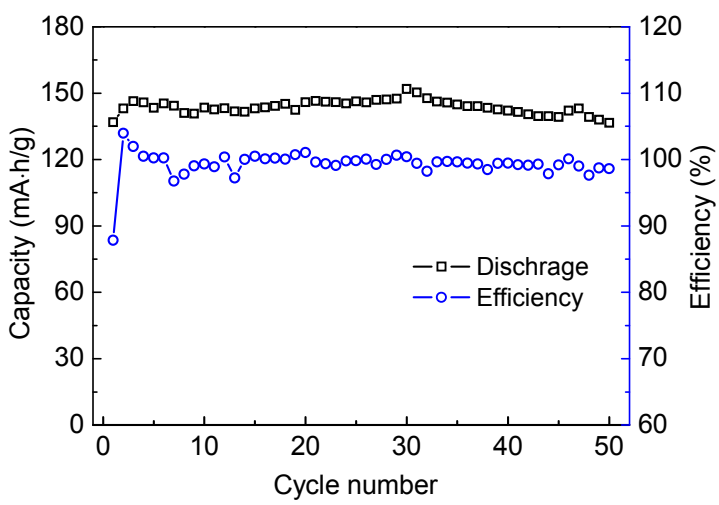

Fig. 6 Specific discharge capacity (a) and efficiency (b) vs. cycle number for $\mathrm{LiFePO}_{4} / \mathrm{IPC} 5 / \mathrm{Li}$ cell at room temperature at $\mathrm{C} / 20$

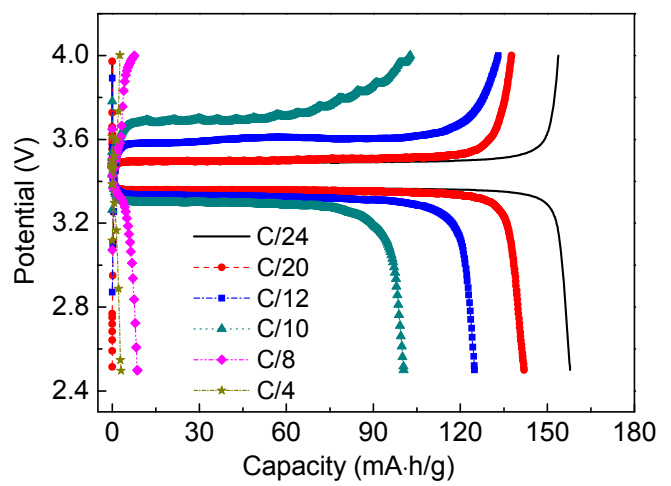

Fig. 7 Charge-discharge capacity at different discharge rates for the $\mathrm{LiFePO}_{4} / \mathrm{IPC} 5 / \mathrm{Li}$ cell at room temperature

\section{Conclusions}

A novel organosilicon-based ionic plastic crystal electrolyte [DTMA][TFSI] was synthesized and its plastic crystal temperature range was from $-26^{\circ} \mathrm{C}$ to $54{ }^{\circ} \mathrm{C}$. By doping the neat OIPC material with $10 \%$ LiODFB and $10 \% \mathrm{PC}$, the [DTMA][TFSI] composite showed a significantly increased ionic conductivity of $1 \times 10^{-4} \mathrm{~S} / \mathrm{cm}$ at $25^{\circ} \mathrm{C}$, which is sufficient to expect operation of battery cells to be possible at room temperature. The $\mathrm{LiFePO}_{4} / \mathrm{Li}$ cell with this plastic crystal as solid-state electrolyte exhibited good cycle performance, with specific capacity of $144 \mathrm{~mA} \cdot \mathrm{h} / \mathrm{g}$ and Coulombic efficiency of $99 \%$ at current density of $\mathrm{C} / 20$, and retained $94 \%$ capacity after 50 cycles. These data demonstrate that these new organosilicon-based ionic plastic crystal composites have considerable potential as solid-state electrolyte materials for use in lithium-ion batteries, particularly in Li metal batteries demanding a stable surface of Li metal as an electrochemical device with equally high energy density as Li-sulfur and Li-air batteries.

\section{References}

Abu-Lebdeh, Y., Abouimrane, A., Alarco, P.J., et al., 2004. Ambient temperature proton conducting plastic crystal electrolytes. Electrochemistry Communications, 6(4): 432-434.

http://dx.doi.org/10.1016/j.elecom.2004.02.015

Alarco, P.J., Abu-Lebdeh, Y., Ravet, N., et al., 2004. Lithium conducting pyrazolium imides plastic crystals: a new solid state electrolyte matrix. Solid State Ionics, 172(1-4): 53-56. http://dx.doi.org/10.1016/j.ssi.2004.02.029

Armel, V., Velayutham, D., Sun, J.Z., et al., 2011. Ionic liquids and organic ionic plastic crystals utilizing small phosphonium cations. Journal of Materials Chemistry, 21(21):7640-7650. http://dx.doi.org/10.1039/c1jm10417a

Forsyth, M., Huang, J., MacFarlane, D.R., 2000. Lithium doped $\mathrm{N}$-methyl- $\mathrm{N}$-ethylpyrrolidinium bis(trifluoromethanesulfonyl)amide fast-ion conducting plastic crystals. Journal of Materials Chemistry, 10(10):2259-2265. http://dx.doi.org/10.1039/b003168m

Glasse, M.D., Idris, R., Latham, R.J., et al., 2002. Polymer electrolytes based on modified natural rubber. Solid State Ionics, 147(3-4):289-294. http://dx.doi.org/10.1016/S0167-2738(02)00024-3

Hammami, A., Raymond, N., Armand, M., 2003. Runaway risk of forming toxic compounds. Nature, 424(6949): 635-636. http://dx.doi.org/10.1038/424635b

Hasegawa, E., Brumfield, M.A., Mariano, P.S., et al., 1988. Photoadditions of ethers, thioethers, and amines to 9, 10dicyanoanthracene by electron-transfer pathways. Journal of Organic Chemistry, 53(23):5435-5442. http://dx.doi.org/10.1021/jo00258a007 
Horike, S., Umeyama, D., Inukai, M., et al., 2012. Coordination-network-based ionic plastic crystal for anhydrous proton conductivity. Journal of the American Chemical Society, 134(18):7612-7615. http://dx.doi.org/10.1021/ja301875x

Howlett, P.C., Sunarso, J., Shekibi, Y., et al., 2011. On the use of organic ionic plastic crystals in all solid-state lithium metal batteries. Solid State Ionics, 204-205:73-79. http://dx.doi.org/10.1016/j.ssi.2011.09.012

Kim, H., Nguyen, D.Q., Bae, H.W., et al., 2008. Effect of ether group on the electrochemical stability of zwitterionic imidazolium compounds. Electrochemistry Communications, 10(11):1761-1764. http://dx.doi.org/10.1016/j.elecom.2008.09.006

MacFarlane, D.R., Forsyth, M., 2001. Plastic crystal electrolyte materials: new perspectives on solid state ionics. Advanced Materials, 13(12-13):957-966. http://dx.doi.org/10.1002/15214095(200107)13:12/13<9 57::AID-ADMA957>3.0.CO;2-\#

MacFarlane, D.R., Meakin, P., Amini, N., et al., 2001. Structural studies of ambient temperature plastic crystal ion conductors. Journal of Physics: Condensed Matter, 13(36):8257-8267. http://dx.doi.org/10.1088/0953-8984/13/36/303

Moriya, M., Watanabe, T., Nabeno, S., et al., 2014. Crystal structure and solid-state ionic conductivity of cyclic sulfonylamide salts with cyano-substituted quaternary ammonium cations. Chemistry Letters, 43(1):108-110. http://dx.doi.org/10.1246/cl.130874

Osman, Z., Ibrahim, Z.A., Arof, A.K., 2001. Conductivity enhancement due to ion dissociation in plasticized chitosan based polymer electrolytes. Carbohydrate Polymers, 44(2):167-173. http://dx.doi.org/10.1016/S0144-8617(00)00236-8

Pringle, J.M., 2013. Recent progress in the development and use of organic ionic plastic crystal electrolytes. Physical Chemistry Chemical Physics, 15(5):1339-1351. http://dx.doi.org/10.1039/C2CP43267F

Qin, X.Y., Wang, J.L., Tang, D.P., et al., 2013. Triethoxysilane with oligo(ethylene oxide) substituent as film forming additive for graphite anode. Journal of Zhejiang University-SCIENCE A (Applied Physics \& Engineering), 14(7):514-519. http://dx.doi.org/10.1631/jzus.A1300026

Rana, U.A., Forsyth, M., MacFarlane, D.R., et al., 2012. Toward protic ionic liquid and organic ionic plastic crystal electrolytes for fuel cells. Electrochimica Acta, 84:213222.

http://dx.doi.org/10.1016/j.electacta.2012.03.058

Rossi, N.A.A., West, R., 2009. Silicon-containing liquid polymer electrolytes for application in lithium ion batteries. Polymer International, 58(3):267-272. http://dx.doi.org/10.1002/pi.2523

Ruther, T., Huang, J., Hollenkamp, A.F., 2007. A new family of ionic liquids based on $N, N$-dialkyl-3-azabicyclo [3.2.2]nonanium cations: organic plastic crystal behaviour and highly reversible lithium metal electrodeposition. Chemical Communications, 48:5226-5228. http://dx.doi.org/10.1039/b709772g

Shekibi, Y., Ruther, T., Huang, J.H., et al., 2012. Realisation of an all solid state lithium battery using solid high temperature plastic crystal electrolytes exhibiting liquid like conductivity. Physical Chemistry Chemical Physics, 14(13):4597-4604. http://dx.doi.org/10.1039/c2cp24077g

Shirota, H., Castner, E.W., 2005. Why are viscosities lower for ionic liquids with $-\mathrm{CH}_{2} \mathrm{Si}\left(\mathrm{CH}_{3}\right)_{3}$ vs $-\mathrm{CH}_{2} \mathrm{C}\left(\mathrm{CH}_{3}\right)_{3}$ substitutions on the imidazolium cations? Journal of Physical Chemistry B, 109(46):21576-21585. http://dx.doi.org/10.1021/jp053930j

Sunarso, J., Shekibi, Y., Efthimiadis, J., et al., 2012. Optimising organic ionic plastic crystal electrolyte for all solidstate and higher than ambient temperature lithium batteries. Journal of Solid State Electrochemistry, 16(5):18411848. http://dx.doi.org/10.1007/s10008-011-1566-6

Taniki, R., Matsumoto, K., Nohira, T., et al., 2014. All solidstate electrochemical capacitors using $\mathrm{N}, \mathrm{N}$ dimethylpyrrolidinium fluorohydrogenate as ionic plastic crystal electrolyte. Journal of Power Sources, 245: 758-763.

http://dx.doi.org/10.1016/j.jpowsour.2013.07.020

Tarascon, J.M., Armand, M., 2001. Issues and challenges facing rechargeable lithium batteries. Nature, 414(6861): 359-367. http://dx.doi.org/10.1038/35104644

Timmermans, J., 1961. Plastic crystals - a historical review. Journal of Physics and Chemistry of Solids, 18(1):1-8. http://dx.doi.org/10.1016/0022-3697(61)90076-2

Unemoto, A., Gambe, Y., Komatsu, D., et al., 2014. Development of high capacity all-solid-state lithium battery using quasi-solid-state electrolyte containing tetraglyme -Li-TFSA equimolar complexes. Solid State Ionics, 262: 765-768. http://dx.doi.org/10.1016/j.ssi.2013.09.043

Wang, Y.F., Zhang, J.M., Cui, X.R., et al., 2013. A novel organic ionic plastic crystal electrolyte for solid-state dye-sensitized solar cells. Electrochimica Acta, 112:247251. http://dx.doi.org/10.1016/j.electacta.2013.08.159

Weng, W., Zhang, Z.C., Lu, J., et al., 2011. A disiloxanefunctionalized phosphonium-based ionic liquid as electrolyte for lithium-ion batteries. Chemical Communications, 47(43):11969-11971. http://dx.doi.org/10.1039/c1cc15331e

Yan, X.D., Zhang, L.Z., 2013. Polyethylene glycol-modified poly(3,4-ethylene dioxythiophene):poly(styrene sulfonate) counter electrodes for dye-sensitized solar cell. Journal of Applied Electrochemistry, 43(6):605-610. http://dx.doi.org/10.1007/s10800-013-0544-3

Yong, T.Q., Wang, J.L., Mai, Y.J., et al., 2014. Organosilicon compounds containing nitrile and oligo(ethylene oxide) substituents as safe electrolytes for high-voltage lithiumion batteries. Journal of Power Sources, 254:29-32. http://dx.doi.org/10.1016/j.jpowsour.2013.12.087

Zhang, H.P., Fu, L.J., Wu, Y.P., et al., 2007. Changes of 
$\mathrm{LiCoO}_{2}$ cathode material for lithium-ion battery during long cycling. Electrochemical and Solid-State Letters, 10(12):A283-A285. http://dx.doi.org/10.1149/1.2789404

Zhang, L.Z., Zhang, Z.C., Harring, S., et al., 2008. Highly conductive trimethylsilyl oligo(ethylene oxide) electrolytes for energy storage applications. Journal of Materials Chemistry, 18(31):3713-3717. http://dx.doi.org/10.1039/b806290k

Zhang, S.S., 2006. An unique lithium salt for the improved electrolyte of Li-ion battery. Electrochemistry Cоттиnications, 8(9):1423-1428. http://dx.doi.org/10.1016/j.elecom.2006.06.016

Zhong, H.X., Zhao, C.B., Luo, H., et al., 2012. Novel organosilicon ionic liquid based electrolytes for supercapacitors. Acta Physico-Chimica Sinica, 28(11):2641-2647. http://dx.doi.org/10.3866/PKU.WHXB201207181

\section{中文概要}

\section{题 目: 新型有机硅基离子塑晶材料作为固态电解质用 于锂离子电池}

目的：合成新型的有机硅基离子塑晶材料 [DTMA][TFSI], 测试材料的物理和电化学性 能, 研究其掺杂改性并作为固态电解质用于锂 离子电池。
创新点: 1. 合成新型的有机硅基离子型塑晶材料; 2. 将 三元复合塑晶材料作为固态电解质在室温下用 于锂离子电池。

方 法: 1. 通过热性能分析, 得到材料的塑晶温度区间 和融化熵值 (图 1 和表 1); 2. 通过电导率测 试, 确定塑晶掺杂对导电性能的影响（图 2); 3. 通过对扣式电池的充放电性能、倍率性能、 循环性能以及阻抗的测试 (图 4 7), 得到塑晶 复合物作为固态电解质的电化学性能以及电池 循环的稳定性和可逆性。

结论: 1 . 合成新型有机硅基离子塑晶材料 $[\mathrm{DTMA}][\mathrm{TFSI}]$, 塑晶温度区间为 $-26{ }^{\circ} \mathrm{C}$ 到 $54{ }^{\circ} \mathrm{C} ; 2$. 在纯塑晶 IPC 中添加 $10 \%$ LiODFB 和 $10 \% \mathrm{PC}$, 得到复合物的电导率为 $1 \times 10^{-4} \mathrm{~S} / \mathrm{cm}$, 提高塑晶作为固态电解质在室温下应用的可行 性; 3. 将复合物用于 $\mathrm{LiFePO}_{4} / \mathrm{Li}$ 半电池测试, 在 $\mathrm{C} / 20$ 倍率下, 电池的放电比容量为 $144 \mathrm{~mA} \cdot \mathrm{h} / \mathrm{g}$, 库伦效率为 $99 \%$ 。在 50 次循环 后, 容量保持率为 $94 \%$; 4. 测试结果表明, 新 型有机硅基离子塑晶的复合物可作为固态电解 质材料应用于锂离子电池, 以及更高能量密度 的锂-硫和锂-空电池。

关键词: 有机硅; 离子塑晶; 固态电解质; 锂离子电池 